\title{
INFLUENCE OF PHYTASE ENZYME ADDITON TO JAPANESE QUAIL RATION ON GROWTH PERFORMANCE, CARCASS CHARACTERISTICS AND SOME BIOCHEMICAL PARAMETERS.
}

\author{
SAKR, O.A*; EL-KEREDY, M.S. ABEER., ${ }^{* *}$ and SABREEN E. FADL ${ }^{* * *}$. \\ * Department of biochemistry, nutritional deficiency disease and toxicology Animal Health Research Institute kafr el sheikh \\ ${ }^{* *}$ Department of biochemistry, nutritional deficiency disease and toxicology Animal Health Research Institute kafr el sheik \\ *** Biochemistry department, Animal Health Research Institute-kafrelshikh.
}

Email: osamaatia119@yahoo.com

\section{ABSTRACT}

Received at: $31 / 12 / 2013$

This experiment was conducted to investigate the effects of phytase, on growth performance, carcass characteristics and some biochemical parameters of Japanese quail fed on low phosphorus diet. Japanese quail were divided into 5 equal groups, each group subdivided into 2 subgroup. One of them contain 16

Accepted: 15/2/2014 males while the other contain 16 females. Japanese quail supplemented with five diets in both Males and females. First group (Positive control) fed on diet contain recommended level of available phosphorus N.R.C. (1994), second group (negative control) fed on diet contain $2 / 3$ recommended level of available phosphorus while the other three groups fed on negative control diet supplemented with $(300,600$ and 900 phytase enzyme unit FTU/Kg), respectively. growth performance results showed that body weight gain of negative control group significantly lowered relative to other groups while Feed conversion ratio of the adequate phosphorus groups or of the low phosphorus groups supplemented with phytase significantly better than the negative control groups in both males and females. The data interested in carcass characteristics showed that dressing percentage. breast and thigh muscles were improved in all dietary treatments in both males and females compared with negative control and significantly increased in groups fed on diet supplemented with (600 \&900 phytase enzyme unit FTU/Kg when compared with the positive control in case of males However leg muscle increased significantly in case of female (900 phytase enzyme unit FTU/Kg) when compared with the positive control. The present data revealed that serum globulin significantly increased in male group fed low phosphorus diet supplemented with 900 phytase relative to other male groups, the serum phosphorus of female group fed low phosphorus diet supplemented with 900 phytase showed significantly higher relative to other female groups.

Keywords: Growth, carcass characteristics, phytase, quail, serum.

\section{INTRODUCTION}

Plant origin feedstuffs such as corn and soybean meal represent the major portion of diets for poultry the availability of phosphorus in plant origin feedstuffs is about 30 to $40 \%$ (NRC, 1994). This low availability is generally attributed to the existence of about $70 \%$ of phosphorus in cereals in the form of phytate (Punna and Roland, 1999). Phytase is the only recognized enzyme that can initiate the release of phosphate from phytin (International Union of Biochemistry, 1979). The addition of the enzyme phytase to grains and feeds was an effective way to increase phosphorus availability to poultry (Nelson et al., 1968) Microbial phytase has a positive influence on the utilization of nutrients other than phosphorus, such as amino acids (Yi et al., 1996; Namkung and Leeson, 1999; Ravindran et al., 1999). The phytase supplementation improved productive performance (Aggoor et al., 2006) it may be possible to reduce supplemental level of inorganic phosphorus with phytase supplementation for quail diets without adverse effect on performance and tibia ash (Ismail et al., 2006) Phytase supplementation increased the availability of phosphorus and subsequently increased body weight and bone mineralization that leads to increasing the bone rigidity in Japanese quail chicks fed low available phosphorus diets. (Osman et al., 2009) Supplementation of phytase to the lowavailable phosphorus diet improved feed conversion 
rate, body weight gain (Lan GanQiu et al., 2012) Plasma total protein and globulin were significantly increased due to phytase supplementation (Attia et al., 2011) Phytase supplementation increased plasma Ca level (Ghahri et al., 2012) phytase improved breast and total meat percentages $(p<0.01$, 0.01 and 0.001 , respectively) These findings suggesting that increased muscle mass is partially responsible for the observed increased in body weight on use of enzyme preparation, Serum total protein, calcium and phosphorus were improved as a result of enzyme supplementation (Abudabos 2012) when the broiler feed is supplemented with phytase and amino acids it is possible to reduce the crud protein, availability phosphorus and Calcium (Gomide et al., 2012) microbial phytase could modify some serum enzyme activities and increase the availability and use of minerals for growth and performance improvement of broilers. It is therefore necessary to re-evaluate mineral requirements of broiler chickens when a diet is supplemented with phytase. (Nourmohammadi et al., 2011) substitution of costly grains by $200 \mathrm{~g} / \mathrm{kg}$ cheaper parboiled rice polish with phytase might reduce the feed cost without affecting feed intake, live weight and meat yield of quails (Sarkar et al., 2011). Byproduct of phytase production can be applicable as chicken feed without giving detrimental effects (Mu KhinSan et al., 2011) therefore the present study was perfomed to investigate the effect of phytase enzyme on growth performance, carcass characteristics and some biochemical parameters of Japanese quail fed on low phosphorus diet.

\section{MATRIALS and METHODS}

\subsection{Experimental Birds:}

A total of 160 healthy Japanese quail 18 day old were used in this experiment. They were obtained from the General Egypt Poultry Organization. They were divided into 5 equal groups: each group subdivided into 2 subgroup. One of them contain 16 males while the other contain 16 females. Males and females of each treatment have the same group number but housed separately.

Each compartment was bedded by fresh clean wood shave forming a deep litter of $4 \mathrm{~cm}$ depth and changed every week. Each compartment was provided with continuous lightening program, suitable feeder and water supply.

Prophylactic antibiotics program measures against the most common infectious bacterial and Newcastle diseases were carried out.

\subsection{Experimental feeding program:}

The present feeding trial was lasted 4 weeks. The diets were formulated according to N.R.C. (1994) for Japanese quail (table 1) and the applied experimental feeding design according L-carnitine level (table 2). Small amounts of the basal diet were first mixed with the respective amounts of phytase as a small batch and then with a larger amount of the basal diets until the total amounts of the respective diets were homogeneously mixed.

Table 1: Physical and chemical composition of the experimental diets.

\begin{tabular}{lccccc}
\hline Physical composition & $\begin{array}{c}\text { positive } \\
\text { control\% }\end{array}$ & $\begin{array}{c}\text { negative } \\
\text { control\% }\end{array}$ & Chemical composition & $\begin{array}{c}\text { positive } \\
\text { control\% }\end{array}$ & $\begin{array}{c}\text { negative } \\
\text { control\% }\end{array}$ \\
\hline Yellow corn & 57.496 & 57.496 & ME Kcal/kg* & 2921 & 2921 \\
Soybean meal (44\%) & 29.8 & 29.8 & Crude protein\% & 24.18 & 24.18 \\
Corn glutine (62\%) & 5 & 5 & Ether Extract\% & 3.017 & 3.017 \\
Fish Meal (60\%) & 5 & 5 & Calcium\% & .8 & .8 \\
lysine & 0.071 & 0.071 & total phosphorus\% & .7 & .59 \\
Dicalcium phosphate & 1 & 0.4 & Availablephosphorus\% & .3 & .2 \\
Lime stone & 0.6 & 1 & Lysine\% & 1.3 & 1.3 \\
Choline (60\%) & 0.333 & 0.333 & Methionine+ cystine\% & .82 & .82 \\
Common salt & 0.4 & 0.4 & Cholin chloride (mg) & $2000 \mathrm{mglkg}$ & $2000 \mathrm{mglkg}$ \\
Premix ** & 0.3 & .03 & & & \\
Sand & 0 & 0.2 & & & \\
\hline
\end{tabular}

** The used premix (Multivita Co.) composed of vitamin A $12000000 \mathrm{IU}$, vitamin $\mathrm{D}_{3} 2200000 \mathrm{IU}$, vitamin E $10000 \mathrm{mg}$, vitamin $\mathrm{K}_{3} 2000 \mathrm{mg}$, vitamin $\mathrm{B}_{1} 1000 \mathrm{mg}$, vitamin $\mathrm{B}_{2} 5000 \mathrm{mg}$, vitamin $\mathrm{B}_{6} 1500 \mathrm{mg}$, vitamin $\mathrm{B}_{12} 10 \mathrm{mg}$, Niacin $30000 \mathrm{mg}$, Biotin $50 \mathrm{mg}$, Folic acid $1000 \mathrm{mg}$, Pantothenic acid $10000 \mathrm{mg}$, Iron $30000 \mathrm{mg}$, Manganese $60000 \mathrm{mg}$, Copper $4000 \mathrm{mg}$, Zinc $50000 \mathrm{mg}$, Iodine $1000 \mathrm{mg}$, Cobalt $100 \mathrm{mg}$, Selenium $100 \mathrm{mg}$, calcium carbonate $\left(\mathrm{CaCO}_{3}\right)$ carrier to $3000 \mathrm{~g}$. 
Table 2: The applied experimental design during the experimental period in both sexes.

\begin{tabular}{cl}
\hline Group & Diet \\
\hline 1 & Positive control contain recommended level of available phosphorus N.R.C. (1994) \\
\hline 2 & Negative control contain 2/3 recommended level of available phosphorus N.R.C. (1994) \\
\hline 3 & Negative control supplemented with 300 phytase enzyme unit ( FTU/Kg) \\
\hline 4 & Negative control supplemented with 600 phytase enzyme unit ( FTU/Kg) \\
5 & Negative control supplemented with 900 phytase enzyme unit ( FTU/Kg) \\
\hline
\end{tabular}

This design used in both sexes at the same arrangement for each treatment.

\subsection{Experimental Parameters:}

2.3.1 Growth performance measurements: Body weight measured according to (Vohra and Roudybush, 1971). Relative growth rate according to Brody (1968). Feed conversion ratio according to (Lambert et al., 1936). And body weight gain. Body weight gain was calculated by the difference between two successive weeks or periods weights.

2.3.2. Dressing percentage, Total edible carcass $\%$ : At the end of growing period (45days), 10 birds were taken randomly from each group $(5$ males and 5 females) weighed and slaughtered to complete bleeding and weighed to determine Abdominal fat, breast muscle, leg muscle, organs weight and their relative weights to body weight. And also to determine biochemical parameters.
2.3.3. Serum total protein was determined according to Duomas et al. (1981), Serum albumin was determined according to Reinhold (1953), Serum globulin was calculated by substract the total serum albumin from total serum protein according to (Coles, 1974). Albumin/ globulin ratio was determined by devision of serum albumin value on serum globulin value according to (Saffinaz, 2001). Calcium and phosphorus measured by flame photometer according to Fuhrman and Crismon, (1951).

\subsection{Statistical analysis:}

The obtained numerical data were statistically analyzed using S.P.S.S., (1997) for one-way analysis of variance. When F- test was significant, least significant difference was calculated according to Duncan (1955).

\section{RESULTS}

\subsection{Growth Performance:}

Table 3: Influence of phytase Enzyme level dietry supplementation on growth performance of male during experimental period (45days):

\begin{tabular}{cccccc}
\hline & \multicolumn{5}{c}{ Groups } \\
\cline { 2 - 6 } Parameter & $\begin{array}{c}\text { Positive } \\
\text { control }\end{array}$ & $\begin{array}{c}\text { Negative } \\
\text { control }\end{array}$ & $\begin{array}{c}\text { Negative } \\
\text { control plus } \\
\text { 300phytase }\end{array}$ & $\begin{array}{c}\text { Negative control } \\
\text { plus 600 phytase }\end{array}$ & $\begin{array}{c}\text { Negative control } \\
\text { plus 900 phytase }\end{array}$ \\
\hline $\begin{array}{c}\text { Initial body } \\
\text { weight }\end{array}$ & $94.48 \pm 1.67 \mathrm{a}$ & $94.27 \pm 2.11 \mathrm{a}$ & $94.58 \pm 1.54 \mathrm{a}$ & $93.94 \pm 1.72 \mathrm{a}$ & $93.9 \pm 1.82 \mathrm{a}$ \\
\hline $\begin{array}{c}\text { final body } \\
\text { weight }\end{array}$ & $211.5 \pm 4.56 \mathrm{bc}$ & $193.75 \pm 4.52 \mathrm{ac}$ & $207.5 \pm 4.36 \mathrm{bc}$ & $205.5 \pm 5.15 \mathrm{c}$ & $211.75 \pm 3.18 \mathrm{bc}$ \\
\hline $\begin{array}{c}\text { Body weight } \\
\text { gain }\end{array}$ & $116.97 \pm 2.99 \mathrm{~b}$ & $99.48 \pm 2.49 \mathrm{a}$ & $112.92 \pm 2.97 \mathrm{~b}$ & $111.56 \pm 3.55 \mathrm{~b}$ & $117.85 \pm 1.39 \mathrm{~b}$ \\
\hline $\begin{array}{c}\text { Feed conversion } \\
\text { Fed }\end{array}$ & $4.33 \pm 0.16 \mathrm{bc}$ & $5 \pm 0.23 \mathrm{ac}$ & $4.45 \pm 0.18 \mathrm{c}$ & $4.49 \pm 0.18 \mathrm{c}$ & $4.21 \pm 0.16 \mathrm{bc}$ \\
\hline
\end{tabular}

Values are expressed as mean \pm standard errors. Means in the same row had different letters significantly differ at $(\mathrm{p}<0.05)$. 
Table 4: Influence of phytase Enzyme level dietry supplementation on growth performance of female during experimental period (45days):

\section{Groups}

\begin{tabular}{cccccc}
\cline { 2 - 5 } Parameter & $\begin{array}{c}\text { Positive } \\
\text { control }\end{array}$ & $\begin{array}{c}\text { Negative } \\
\text { control }\end{array}$ & $\begin{array}{c}\text { Negative } \\
\text { control plus } \\
\text { 300phytase }\end{array}$ & $\begin{array}{c}\text { Negative control } \\
\text { plus 600 phytase }\end{array}$ & $\begin{array}{c}\text { Negative control } \\
\text { plus 900 phytase }\end{array}$ \\
\hline $\begin{array}{c}\text { Initial body } \\
\text { weight }\end{array}$ & $93.28 \pm 2.19 \mathrm{a}$ & $94.16 \pm 1.79 \mathrm{a}$ & $93.36 \pm 2.25 \mathrm{a}$ & $93.19 \pm 1.83 \mathrm{a}$ & $92.98 \pm 1.89 \mathrm{a}$ \\
\hline $\begin{array}{c}\text { final body } \\
\text { weight }\end{array}$ & $216.88 \pm 3.76 \mathrm{bc}$ & $191.75 \pm 4.89 \mathrm{ac}$ & $203.88 \pm 6.08 \mathrm{c}$ & $214.63 \pm 5.06 \mathrm{bc}$ & $213.38 \pm 4.99 \mathrm{bc}$ \\
\hline $\begin{array}{c}\text { Body weight } \\
\text { gain }\end{array}$ & $123.54 \pm 1.76 \mathrm{c}$ & $97.59 \pm 3.34 \mathrm{a}$ & $110.52 \pm 3.98 \mathrm{~b}$ & $121.44 \pm 3.25 \mathrm{c}$ & $120.4 \pm 3.17 \mathrm{c}$ \\
\hline $\begin{array}{c}\text { Feed } \\
\text { conversion }\end{array}$ & $4.17 \pm 0.15 \mathrm{~b}$ & $5.22 \pm 0.25 \mathrm{a}$ & $4.52 \pm 0.19 \mathrm{~b}$ & $4.14 \pm 0.15 \mathrm{~b}$ & $4.23 \pm 0.16 \mathrm{~b}$ \\
\hline
\end{tabular}

Values are expressed as mean \pm standard errors. Means in the same row had different letters significantly differ at $(p<0.05)$.

\subsection{Carcass Characteristics:}

Table 5: Influence of phytase Enzyme level dietry supplementation on Carcass traits percentage of male at the end of experimental period (45days):

\begin{tabular}{|c|c|c|c|c|c|}
\hline \multirow[b]{2}{*}{ Item } & \multicolumn{5}{|c|}{ Groups } \\
\hline & $\begin{array}{l}\text { Positive } \\
\text { control }\end{array}$ & $\begin{array}{l}\text { Negative } \\
\text { control }\end{array}$ & $\begin{array}{l}\text { Negative } \\
\text { control plus } \\
\text { 300phytase }\end{array}$ & $\begin{array}{c}\text { Negative } \\
\text { control } \\
\text { plus } 600 \\
\text { phytase }\end{array}$ & $\begin{array}{l}\text { Negative control } \\
\text { plus } 900 \text { phytase }\end{array}$ \\
\hline Dressing \% & $68.24 \pm 0.53 b$ & $65 \pm 0.81 \mathrm{a}$ & $68.44 \pm 0.92 b$ & $68.16 \pm 0.13 b$ & $69.34 \pm 0.82 b$ \\
\hline Head \% & $4.93 \pm 0.14 \mathrm{c}$ & $5.09 \pm 0.07 \mathrm{c}$ & $5.1 \pm 0.09 \mathrm{c}$ & $5.13 \pm 0.07 b c$ & $4.86 \pm 0.03 \mathrm{ac}$ \\
\hline Liver $\%$ & $1.96 \pm 0.14 \mathrm{a}$ & $1.97 \pm 0.11 \mathrm{a}$ & $1.92 \pm 0.13 \mathrm{a}$ & $1.98 \pm 0.18 \mathrm{a}$ & $1.98 \pm 0.12 \mathrm{a}$ \\
\hline Heart \% & $1.07 \pm 0.06 \mathrm{a}$ & $1.08 \pm 0.08 \mathrm{a}$ & $1.06 \pm 0.11 \mathrm{a}$ & $1.01 \pm 0.06 \mathrm{a}$ & $1.07 \pm 0.07 \mathrm{a}$ \\
\hline Gizzard \% & $2.39 \pm 0.08 \mathrm{a}$ & $2.44 \pm 0.09 \mathrm{a}$ & $2.39 \pm 0.07 \mathrm{a}$ & $2.45 \pm 0.08 \mathrm{a}$ & $2.34 \pm 0.05 \mathrm{a}$ \\
\hline Breast Muscle \% & $17.12 \pm 0.15 b$ & $16.01 \pm 0.08 \mathrm{a}$ & $17.07 \pm 0.15 b$ & $18.5 \pm 0.36 c$ & $18.14 \pm 0.38 \mathrm{c}$ \\
\hline Leg Muscle \% & $12.92 \pm 0.06 \mathrm{~b}$ & $11.9 \pm 0.09 \mathrm{a}$ & $13.37 \pm 0.14 \mathrm{c}$ & $13.26 \pm 0.13 c$ & $13.66 \pm 0.05 \mathrm{c}$ \\
\hline Abdominal Fat \% & $0.53 \pm 0.05 a$ & $0.59 \pm 0.04 \mathrm{a}$ & $0.55 \pm 0.03 \mathrm{a}$ & $0.55 \pm 0.06 \mathrm{a}$ & $0.56 \pm 0.07 \mathrm{a}$ \\
\hline
\end{tabular}

Values are expressed as mean \pm standard errors. Means in the same row had different letters significantly differ at $(p<0.05)$ 
Table 6: Influence of phytase Enzyme level dietry supplementation on Carcass traits percentage of female at the end of experimental period (45days):

\begin{tabular}{cccccc}
\hline & \multicolumn{3}{c}{ Groups } & & \\
\cline { 2 - 5 } item & $\begin{array}{c}\text { Positive } \\
\text { control }\end{array}$ & $\begin{array}{c}\text { Negative } \\
\text { control }\end{array}$ & $\begin{array}{c}\text { Negative } \\
\text { control plus } \\
\mathbf{3 0 0 p h y t a s e}\end{array}$ & $\begin{array}{c}\text { Negative } \\
\text { control } \\
\text { plus 600 } \\
\text { phytase }\end{array}$ & $\begin{array}{c}\text { Negative } \\
\text { control } \\
\text { plus 900 } \\
\text { phytase }\end{array}$ \\
\hline Dressing \% & $66.07 \pm 0.07 \mathrm{c}$ & $64.39 \pm 0.55 \mathrm{ab}$ & $65.67 \pm 0.57 \mathrm{bc}$ & $68.04 \pm 0.78 \mathrm{~d}$ & $67.62 \pm 0.42 \mathrm{~cd}$ \\
\hline Head \% & $4.69 \pm 0.03 \mathrm{a}$ & $4.74 \pm 0.07 \mathrm{a}$ & $4.61 \pm 0.08 \mathrm{a}$ & $4.58 \pm 0.06 \mathrm{a}$ & $4.68 \pm 0.04 \mathrm{a}$ \\
\hline Liver \% & $2.43 \pm 0.06 \mathrm{a}$ & $2.38 \pm 0.03 \mathrm{a}$ & $2.4 \pm 0.08 \mathrm{a}$ & $2.37 \pm 0.06 \mathrm{a}$ & $2.44 \pm 0.04 \mathrm{a}$ \\
\hline Heart \% & $0.93 \pm 0.05 \mathrm{a}$ & $0.91 \pm 0.04 \mathrm{a}$ & $0.93 \pm 0.05 \mathrm{a}$ & $0.92 \pm 0.06 \mathrm{a}$ & $0.92 \pm 0.06 \mathrm{a}$ \\
\hline Gizzard \% & $2.44 \pm 0.03 \mathrm{a}$ & $2.45 \pm 0.04 \mathrm{a}$ & $2.38 \pm 0.08 \mathrm{a}$ & $2.36 \pm 0.06 \mathrm{a}$ & $2.43 \pm 0.05 \mathrm{a}$ \\
\hline Breast Muscle \% & $17.17 \pm 0.13 \mathrm{~b}$ & $15.57 \pm 0.17 \mathrm{ab}$ & $16.58 \pm 1.16 \mathrm{~b}$ & $17.87 \pm 0.27 \mathrm{bc}$ & $17.85 \pm 0.24 \mathrm{bc}$ \\
\hline Leg Muscle \% & $12.77 \pm 0.08 \mathrm{~b}$ & $11.62 \pm 0.18 \mathrm{a}$ & $12.72 \pm 0.08 \mathrm{~b}$ & $12.66 \pm 0.14 \mathrm{~b}$ & $13.21 \pm 0.21 \mathrm{c}$ \\
\hline Abdominal Fat \% & $0.55 \pm 0.11 \mathrm{a}$ & $0.56 \pm 0.07 \mathrm{a}$ & $0.59 \pm 0.07 \mathrm{a}$ & $0.58 \pm 0.08 \mathrm{a}$ & $0.58 \pm 0.07 \mathrm{a}$ \\
\hline
\end{tabular}

Values are expressed as mean \pm standard errors. Means in the same row had different letters significantly differ at $(p<0.05)$.

\section{3. biochemicl parameters:}

Table 7: Influence of phytase Enzyme level dietry supplementation on biochemicl parameteres of male at the end of experimental period (45days):

\begin{tabular}{cccccc}
\hline & \multicolumn{3}{c}{ Groups } & & \\
\cline { 2 - 5 } Item & $\begin{array}{c}\text { Positive } \\
\text { control }\end{array}$ & $\begin{array}{c}\text { Negative } \\
\text { control }\end{array}$ & $\begin{array}{c}\text { Negative } \\
\text { control plus } \\
\text { 300phytase }\end{array}$ & $\begin{array}{c}\text { Negative } \\
\text { control } \\
\text { plus 600 } \\
\text { phytase }\end{array}$ & $\begin{array}{c}\text { Negative } \\
\text { control } \\
\text { plus 900 } \\
\text { phytase }\end{array}$ \\
\hline Total Serum protein(g/dl) & $4.03 \pm 0.24 \mathrm{c}$ & $3.67 \pm 0.12 \mathrm{ac}$ & $3.4 \pm 0.06 \mathrm{a}$ & $4.03 \pm 0.23 \mathrm{c}$ & $4.37 \pm 0.09 \mathrm{bc}$ \\
\hline Serum albumin(g/dl) & $1.83 \pm 0.12 \mathrm{a}$ & $1.5 \pm 0.12 \mathrm{a}$ & $1.43 \pm 0.09 \mathrm{a}$ & $1.8 \pm 0.21 \mathrm{a}$ & $1.8 \pm 0.06 \mathrm{a}$ \\
\hline Serum globulin(g/dl) & $2.2 \pm 0.15 \mathrm{~b}$ & $2.17 \pm 0.03 \mathrm{~b}$ & $1.97 \pm 0.07 \mathrm{~b}$ & $2.23 \pm 0.03 \mathrm{~b}$ & $2.57 \pm 0.13 \mathrm{a}$ \\
\hline Albumin /globulin ratio & $0.84 \pm 0.06 \mathrm{a}$ & $0.69 \pm 0.05 \mathrm{a}$ & $0.73 \pm 0.07 \mathrm{a}$ & $0.80 \pm 0.08 \mathrm{a}$ & $0.73 \pm 0.06 \mathrm{a}$ \\
\hline Serum Calcium(M Eq/g) & $8.11 \pm 0.91 \mathrm{a}$ & $8.10 \pm 0.69 \mathrm{a}$ & $7.99 \pm 0.92 \mathrm{a}$ & $9.19 \pm 0.45 \mathrm{a}$ & $8.39 \pm 1.22 \mathrm{a}$ \\
\hline Serum phosphorus(M Eq/g) & $13.22 \pm 0.37 \mathrm{a}$ & $11.50 \pm 0.84 \mathrm{a}$ & $10.77 \pm 2.28 \mathrm{a}$ & $9.4 \pm 0.22 \mathrm{a}$ & $15.1 \pm 3.5 \mathrm{a}$ \\
\hline
\end{tabular}

Values are expressed as mean \pm standard errors. Means in the same row had different letters significantly differ at $(\mathrm{p}<0.05)$. 
Table 8: Influence of phytase Enzyme level dietry supplementation on biochemicl parameteres of female at the end of experimental period

\begin{tabular}{|c|c|c|c|c|c|}
\hline \multirow[b]{2}{*}{ Item } & \multicolumn{5}{|c|}{ Groups } \\
\hline & Positive control & $\begin{array}{l}\text { Negative } \\
\text { control }\end{array}$ & $\begin{array}{l}\text { Negative } \\
\text { control plus } \\
\text { 300phytase }\end{array}$ & $\begin{array}{l}\text { Negative control } \\
\text { plus } 600 \text { phytase }\end{array}$ & $\begin{array}{c}\text { Negative } \\
\text { control } \\
\text { plus } 900 \\
\text { phytase }\end{array}$ \\
\hline Total Serum protein $(\mathrm{g} / \mathrm{dl})$ & $4.33 \pm 0.09 a$ & $4.17 \pm 0.12 \mathrm{a}$ & $4.3 \pm 0.31 \mathrm{a}$ & $4.17 \pm 0.03 \mathrm{a}$ & $4.6 \pm 0.15 \mathrm{a}$ \\
\hline Serum albumin $(\mathrm{g} / \mathrm{dl})$ & $1.73 \pm 0.09 \mathrm{a}$ & $1.87 \pm 0.12 \mathrm{a}$ & $1.8 \pm 0.25 \mathrm{a}$ & $1.77 \pm 0.03 \mathrm{a}$ & $2.13 \pm 0.12 \mathrm{a}$ \\
\hline Serum globulin $(\mathrm{g} / \mathrm{dl})$ & $2.6 \pm 0.15 \mathrm{ac}$ & $2.33 \pm 0.03 b c$ & $2.5 \pm 0.06 \mathrm{c}$ & $2.4 \pm 0 \mathrm{c}$ & $2.47 \pm 0.07 \mathrm{c}$ \\
\hline Albumin/globulin ratio & $0.67 \pm 0.07 \mathrm{a}$ & $0.8 \pm 0.06 \mathrm{a}$ & $0.73 \pm 0.1 \mathrm{a}$ & $0.73 \pm 0.02 \mathrm{a}$ & $0.86 \pm 0.05 a$ \\
\hline Serum Calcium(M Eq/g) & $9.57 \pm 0.5 \mathrm{a}$ & $9.59 \pm 0.15 \mathrm{a}$ & $8.31 \pm 0.95 \mathrm{a}$ & $10.09 \pm 0.08 \mathrm{a}$ & $10.13 \pm 0.72 \mathrm{a}$ \\
\hline Serum phosphorus(M Eq/g) & $11.34 \pm 1.86 \mathrm{bd}$ & $12.67 \pm 0.84 \mathrm{~d}$ & $15.53 \pm 1.11 \mathrm{~cd}$ & $13.06 \pm 1.07 \mathrm{~d}$ & $19.29 \pm 0.33 \mathrm{a}$ \\
\hline
\end{tabular}

Values are expressed as mean \pm standard errors. Means in the same row had different letters significantly differ at $(p<0.05)$.

The analysis of variance of obtained data of growth performance presented in tables $(3 \& 4)$ showed that body weight gain of the low phosphorus groups without phytase was significantly lowered relative to other groups in both males and females, while feed conversion ratio of the adequate phosphorus groups or of the low phosphorus one supplemented with phytase significantly better than group fed on diet low- available phosphorus without phytase.

The statical analysis of the obtained data regarding carcass traits percentage illustrated in tables $(5 \& 6)$ demonstrated that dressing percentage of male groups increased significantly in groups supplemented with phytase compared with the negative control, while breast and leg muscle improved significantly with phytase supplemented diet (600 \& 900 phytase enzyme unit FTU/Kg) when compared with both the negative and positive control. However dressing percentage of female groups increased significantly in birds fed on diet supplemented with600 and 900 phytase enzyme unit FTU/Kg when compared with both the negative and positive control and female group fed on diet supplemented with900phytase enzyme unit FTU/Kg improved significantly when compared also with both the negative and positive control.

The data concerning biochemicl parameteres represented in tables $(7 \& 8)$ revealed that no significant differences in serum total Protein, albumin, globulin Albumin/globulin ratio Calcium and phosphorus in both male and female groups except Serum globulin significantly increased in males fed low phosphorus diet supplemented with 900 phytase relative to other male groups, and Serum phosphorus of females fed low phosphorus diet supplemented with 900 phytase showed significant higher relative to other female groups.

\section{DISCUSSION}

This results concerning growth performance are in agreement with those obtained by Shaw et al. (2011) who found a reducing dietary non-phytate phosphorus requires phytase supplementation to obtain normal growth performance. The present results are in accordance with Motawe et al. (2012) who added phytase500 U phytase $/ \mathrm{Kg}$ to the basal diet and he found a significant improved body weight gain and. feed conversion ratio. In contrast to our results Rekhate et al. (2011) supplemented of Ayuphytase with reduced dicalcium phosphate level at 50 and $65 \%$ and he found the supplementation could not effective to achieve performance of broilers in terms of gain in weight.

These results agreed with the findings reported by Abou-Ashour et al. (2011) who found that the dressing percentage was significantly increased with phytase dietry supplementation compared to the negative control (low available phosphorus). The obtained data confirmed by Jadhav et al. (2011) who supplemented chicken Phytase at a level $500 \mathrm{FTU} / \mathrm{kg}$ and he found that the chicken fed this diet recorded significant higher dressing yield. The results supported also by Abudabos (2012) who mentioned an enzyme supplementation (phytase) significantly improved breast and total meat percentages. The obtained results were disagree with those obtained by (Rekhate et al., 2011) who found that a supplementation of Ayuphytase with reduced dicalcium phosphate level at 50 and $65 \%$ could not be effective to achieve performance of broilers in terms carcass.

The findings of biochemicl parameteres incase of male similar to those obtained Attia et al. (2011) 
Plasma globulin significantly increased due to phytase supplementation. While the data of female similar to those obtained by Abou-Ashour et al. (2011) who demonstrated that Plasma phosphorus were increased at 6000 and $12000 \mathrm{U}$ phytase/kg diet. The findings supported by those obtained by Ghahri et al. (2012) who found that the Serum total protein, calcium and phosphorus were improved as a result of phytase supplementation.

\section{CONCLUSION}

It could be concluded that supplementation of phytase Enzyme could be effective to achieve performance of Japanese quail fed on reduced level of available phosphorus at $2 / 3$ of recommended level (N.R.C1994) and showed better results in some parameters than the Japanese quail fed on adequate phosphorus diet.

\section{REFERENCES}

Abou-Ashour, A.M.H.; El-Rahman, S.A.A.A.; Zanaty, G.A.and Abou-Elnaga, M.K. (2011): Effect of phytase supplementation on phytate phosphorous utilization and related parameters in broiler chickens. Proceedings of the 4th Scientific Conference of Animal Wealth Research in the Middle East and North Africa, Foreign Agricultural Relations (FAR), Egypt, 3-5 October 2011; 375-394.

Abudabos, A.M. (2012): Effect of enzyme supplementation to normal and low density broiler diets based on corn-soybean meal. Asian Journal of Animal and Veterinary Advances; 7: 2, 139-148. 29 ref.

Aggoor, F.A.M.; Attia, Y.A.; Ismail, F.S.A.; Qota, E.M.A. and Shakmak, E.A. (2006): Effect of level and source of dietary energy and/or enzyme additions on productive performance and egg quality of Japanese quail hens. EPC 2006 - 12th European Poultry Conference, Verona, Italy, 10-14 September. paper 55. 15

Attia, Y.A.; Zeweil, H.S.; Alsaffar, A.A and El-Shafy, A.S. (2011): Effect of non-antibiotic feed additives as an alternative to flavomycin on productivity, meat quality and blood parameters in broilers. Archiv fur Geflugelkunde; 75: 1, 40-48. 44 ref.

Brody, S. (1968): Bioenergetics and growth. Hafner Publ. Comp. N.Y.

Coles, E.H. (1974): Veterinary clinical pathology. $2^{\text {nd }}$ Ed. W. B. Saunders Company, Philadelphia and London..

Duncan, D.B. (1955): Multiple Ranges and Multiple F - test. Biometerics, 11:1-42.

Duomas, B.T.; Bayso; D.D.; Carter, R.J.; Peters, T. and Schaffer, R. (1981): Determination of total serum protein. Clin. Chem., 27: 1642-1643.
Fuhrman, F.A. and Crismon, J.M. (1951): Am. J. Physiol., 188,424 (1951)

Ghahri, H.; Rostami, D.; Zandiyeh, M.A. and Abbasi, R.H. (2012): The effects of phytase on performance, serum mineral levels, enzyme activities and immune function of broilers fed Nutritionally Marginal Diets. Middle East Journal of Scientific Research; 11: 11, 14811490. 34 ref.

Gomide, E.M.; Rodrigues, P.B.; Naves, L. de P.; Bernardino, V.M.P.; Santos, L.M. dos and Garcia, A.A.P. (2012): Diets with reduced levels of nutrients supplemented with phytase and amino acids for broilers. Ciencia e Agrotecnologia. 36: 1, 100-107. 23 ref.

International Union of Biochemistry, (1979): Pp. 242-247 in: Enzyme Nomenclature: Recommendations of the Nomenclature Committee of the International Union of Biochemistry. Academic Press, New York, NY

Ismail, F.S.A.; Attia, Y.A.; Aggoor, F.A.M.; Qota, E.M.A. and Shakmak, E.A. (2006): Effect of energy level, rice by products and enzyme additions on carcass yield, meat quality and plasma constituents of Japanese quail. EPC 2006 -2006 12th European Poultry Conference, Verona, Italy, 10-14 September; paper 56. 20 ref.

Jadhav, N.V.; Suranagi, M.D.; Anjaneya, S.N.; Prakashchandra and Mallikarjunappa, $S$. (2011): Effect of replacing soybean meal and dicalcium phosphate in the diets with alternative ingredients and phytase supplementation on growth and nutrient balance in broiler chicken. Animal Nutrition and Feed Technology; 11: 2, 203-210.

Lambert, W.V.; Ellis, N.R.; Block, W.H. and Titus, H.W. (1936): The role of nutrition in genetics. Amer. Res. Soc. Animal Prod., Vol. 29:236.

Lan GanQiu; Norhani Abdullah; Syed Jalaludin and Ho YinWan (2012): Effects of freeze-dried Mitsuokella jalaludinii culture and NatuphosReg. phytase supplementation on the performance and nutrient utilisation of broiler chickens. Journal of the Science of Food and Agriculture; 92: 2, 266-273. 49 ref.

Motawe, H.F.A.; El-Afifi, T.M.; Hassan, H.M.A. and Attia, Y.A. (2012): Addition of phytase to broiler diets contained different lysine leve Egyptian Poultry SciencJournal; 32: 1, 117130. 38 ref.

Mu KhinSan; Azhar Bin Kasim; Aini Ideris and Che Roos Saad (2011): Effect of fermented rice bran, bio-converted byproduct on performance of broiler chickens. Journal of Animal and Veterinary Advances;. 10: 22, 2990-2995. 30 ref.

Namkung, H. and Leeson, S. (1999): Effect of phytase enzymeon dietary nitrogen-corrected apparent metabolizable energyand ileal 
digestibility of nitrogen and amino acids in broilerchicks. Poult. Sci. 78: 1317-1319.

Nelson, T.S.; Shieh, T.R.; Wodzinski, R.J. and Ware, J.H. (1968): The availability of phytatephosphorus in soybean meal before and after treatment with a mold phytase. Poul. sci., 47:1842-1848

Nourmohammadi, R.; Hosseini, S.M. and Farhangfar, $H$. (2011): Effect of citric acid and microbial phytase on serum enzyme activities and plasma minerals retention in broiler chicks. African Journal of Biotechnology; 10: 62, 1364013650. 36 ref.

NRC (1994): Nutrient requirements of poultry, ninth revised edition, National Academy Press, Washington DC

Osman, E.S.; Maksoud, A.M.A.; Salem, A.A. and Elatar, A.H. (2009): Tibia characteristics and strength in Japanese quail fed low phosphorus diets supplemented with microbial phytase. Egyptian Poultry Science Journal. 29: 1, 323336. 25 ref.

Punna, S. and Roland, D.A Sr. (1999): Variation in phytate phosphorus utilization within the same broiler srain.J. App. Poult.Res., 8:10-15.

Ravindran, V.; Cabahug, S.; Ravindran, G. and Bryden, W.L. (1999): Influence of microbial phytase on apparent ileal aminoacid digestibility of feedstuffs for broilers. Poult. Sci.78:699-706

Reinhold, D.G. (1953): The principle diseases of lower vertebrates. Academic Press, London, 600 pp.
Rekhate, D.H.; Maini, S.; Meena, M.K. and Datir, D.K. (2011): Effect of ayuphytase on inclusion of inorganic phosphorus source in broiler diet. Indian Journal of Animal Production and Management; 27: 1/2, 1-4. 15 ref.

S.P.S.S. (1997): Statistical package for the social sciences, Revisions 6, spss Inc, Chicago, USA.

Saffinaz, G.M.I. (2001): Effect of phenol on immune response of Tilapia fish and susceptability to disease. ph.D. Thesis Fac.of Vet. Med. Suez Canal Univ.

Sarkar, D.K.; Mahiuddin, M.; Ali, M.S.; Azad, M.M.H.; Howlider, M.A.R. (2011): Exogenous phytase for better utilization of parboiled rice Polish based diet on the growth and meat yield of Japanese quail. Bangladesh Journal of Animal Science; 40: 1/2, 8-12. 24 ref.

Shaw, A.L.; Ginkel, F.W. van; Macklin, K.S and Blake, J. P. (2011): Effects of phytase supplementation in broiler diets on a natural Eimeria challenge in naive and vaccinated birds. Poultry Science; 90: 4, 781-790.

Vohra, P. and Roudybush, I. (1971): The effect of various levels of dietary protein on the growth and egg production of cotournix cotournix japonica. Poultry Sci. 50: 1081-1084

Yi, Z.; Kornegay, E.T. and Denbow, D.M. (1996): Effect of microbial phytase on nitrogen and amino acid digestibility and nitrogen retention of turkey poults fed corn-soybean meal diets. Poult. Sci. 75:979-990.

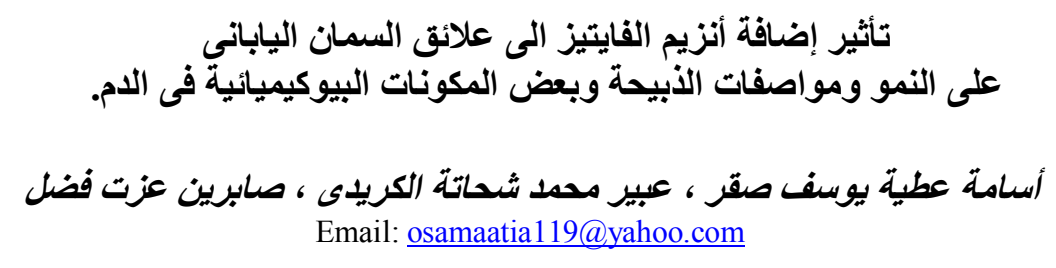

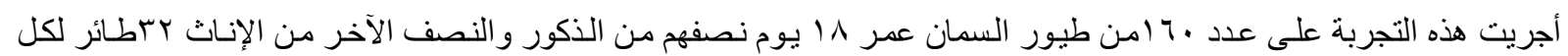

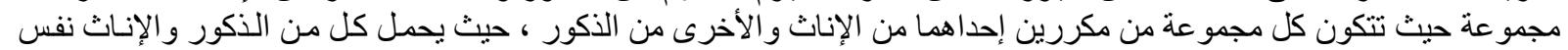

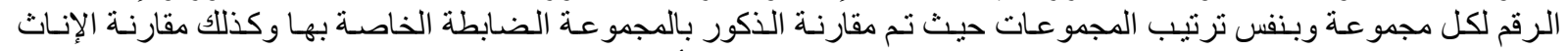

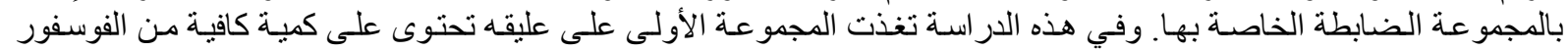

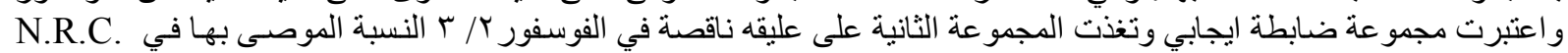

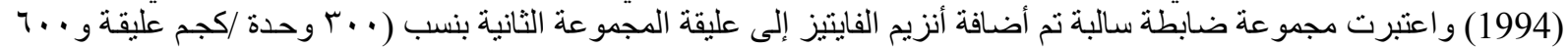

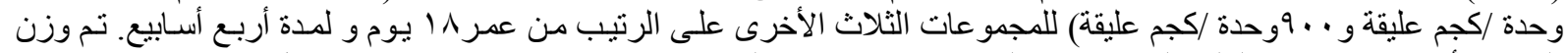

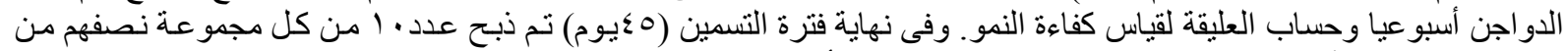

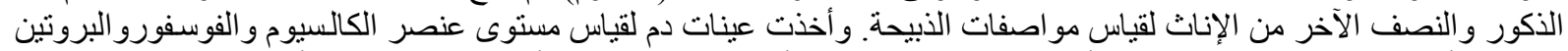

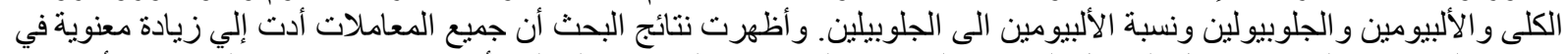

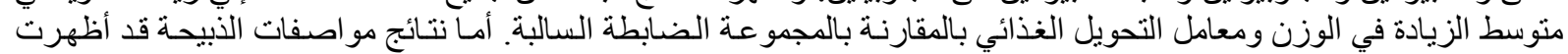

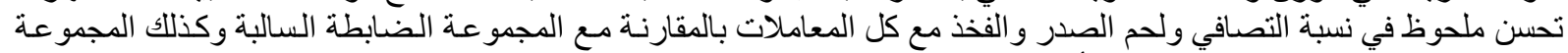

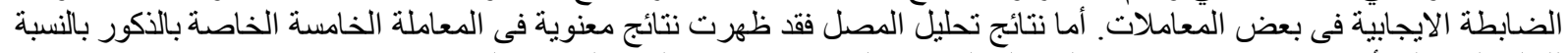

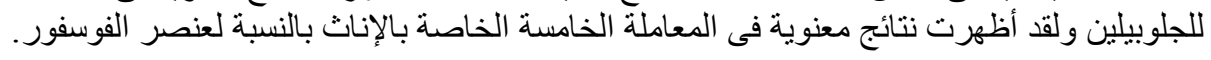

الخلاصة: إضافة أنزيم الفايتيز يحقق نتائج ايجابية على النمو ومو اصفات الذبيحة وبعض المكونات البيوكيميائية للسمان اليابانى. 